\begin{tabular}{|c|c|c|}
\hline $\begin{array}{l}\text { EXCELLENT } \\
\text { PUBLLSHERS }\end{array}$ & $\begin{array}{l}\text { International Journal of Current Research } \\
\text { and Academic Review } \\
\text { ISSN: 2347-3215 (Online):,: Volume } 5 \\
\text { Journal homepage: http://www.ijcrar.com } 7 \text { (July-2017) }\end{array}$ & \\
\hline
\end{tabular}

doi: $\underline{\text { https://doi.org/10.20546/ijcrar.2017.507.003 }}$

\title{
The Study of Achievement Motivation and Gender as Correlates of Academic Achievement among Degree Students in Puducherry, India
}

\author{
M. Rosalind Prabha* \\ Department of Psychology, Govt. Tagore Arts College, Puducherry, India \\ *Corresponding author
}

\begin{abstract}
The Importance of Education for all round growth and development of an Individual is very well understood by the researchers and as such several research studies where undertaken in various fields of education in India and Abroad. Among the areas studied most of the researchers have focused on Academic Achievement and its correlates to Analyze and enhance performance at various levels. It's only in the light of the facts mentioned that this study was undertaken to find out the correlation if any between Achievement motivation and Gender with that of Academic Achievement among First year Degree students covering all disciplines such as Arts, Science and Engineering in Puducherry-India. The findings of the study have clearly established significant correlation between Academic Achievement with that of Gender (Sex) of students. As far as this study is concerned the results didn't establish any significant correlation between Academic Achievement and Achievement Motivation among First year Degree students in Puducherry-India.
\end{abstract}

\section{Article Info}

Accepted: 02 July 2017

Available Online: 20 July 2017

\section{Keywords}

Academic achievement, Achievement motivation, Gender,

Degree students (First Year), Puducherry.

\section{Introduction}

It is high time that researchers concentrate on topics and areas pertaining to performance and achievement of students at Degree level so that so much of money spent on Higher Education viz Arts, Science and Engineering yields desired fruits in the form of quality products Scholars - who could shape the future of India as one among the most advanced countries in the world in terms of Prosperity, Knowledge, Technology, Creativity, Innovation and Talented Man Power. For this vision to be realised correlative studies should be aimed at for better understanding of various associated variables and factors that contributes towards very best performance and achievement at the level of Higher Education so that Social, Economic and Educational Planners could formulate new strategies to achieve the best out of Millions of young and dynamic youth in India.

It is only in the light of the above point of view expressed that this research study was focused on the correlation of Achievement Motivation and Gender with that of Academic Achievement among Degree students (First Year) in the Union Territory of Puducherry.

\section{The significance of academic achievement-an overview}

Education is the basic requirement of any human being to understand, identify and develop the latent talents, skills and potentialities. It starts at the age of four and goes on until one wishes to acquire the same. As such 
age in no bar for acquiring knowledge and learning new things in any field of activity. It does not only lead to individual development but ultimately results in the growth of the Nation.

The importance of achievement and best performance needs no explanation or introduction. Hence it is only through very best performance and Achievement that the goals and objectives of Education are realised. As such Academic Achievement and success at all levels of study has been a very favourite topic of research for years together.

Many researchers in the field of Education have highlighted the importance of education through their findings. Researchers such as Verma (1990), Ramaswamy (1990), Sajaya et al., (1963), Jamuar (1974), Cobbach (1989), Bansal (1994) and Crow and Crow (1969) have contributed a lot towards understanding of the importance and significance of Academic Achievement and Success.

UNESCO the World Body as well as UGC and NCERT have taken various efforts towards enhancement of academic success and performance. The other organisations such as ICSSR, ICSR, SCERT, NAC, RIES, 11TS,11S, 11MS etc. have undertaken several type of research studies towards improvement of quality, creativity and innovation in Arts, Science, Engineering of Technology. Thus throughout the world every effort is taken to improve performance and academic success of students at all levels.

Human being the very best and unique creation of GOD is always blessed with the superior intelligence than any other being on earth. As such to make the best use of this intelligence as well to apply the same at work is very much required and expected of any individual to be most successful in life and career. As such Schools, Colleges, Institutes and Universities play a significant role in shaping the personality of child or student towards best performance and achievement. Hence academic achievement is considered as a very significant criterion to assess one's potentialities and capacities. Thus academic achievement plays a very important role in education as well as in the teaching learning process.

It is only in the light of the facts expressed that utmost importance is given to the study of correlates of academic achievement so that, research and findings would throw much light on the ways and means by which academic achievement and performance of student could be improved or enhanced. This research is also aimed and designed in the backdrop of the facts mentioned so that the findings of variables studied would be much beneficial to Educational and Social Planners in India and abroad.

\section{Motivation and its importance in the teaching- learning process}

1. It is important for the teacher to know the basic needs of his/her students and cater for these according to level of their importance. For example, the teacher needs to think first of students' food, rest or health before thinking of teaching them.

2. When the teacher praises his/her students for doing well in their study or assignment, they will be spurred to sustain that effort.

3. A classroom which is well decorated or adorned with beautiful charts and learning materials will be students' friendly. The students' minds will always be attracted to the activities in a beautifully adorned classroom.

4. In the classroom, students like being recognized or respected. When their views are recognized or respected, they will have their confidence boosted and developed.

5. From the beginning of the lesson, the teacher should endeavour to make his/her students know possible outcome of the lesson. It is when the students know what they are likely to achieve from the lesson that their attention will be arrested and sustained.

6. Feedback is necessary if the interest of the students must be sustained in the classroom. So the teacher should always strive to let them know how they are performing in the teaching-learning activities.

7. The teacher should also provide/plan for extracurricular activities for his/her students. When the teacher does this, the students will have opportunity of establishing a genuine interaction among them. Besides, they will be able to showcase their hidden talents.

8. When dealing with the students in the classroom, the teacher should take into consideration, the developmental changes and differences in the 
students before deciding on the particular motivation pattern to be employed.

\section{Achievement motivation and success}

The motive to achieve with all self-determination is nothing but achievement motivation. The research studies carried out by Gesinde (2000) have brought out the knowledge about the motive to achieve. According to his studies, the urge to achieve varies from one individual to the other. Some individual's need for achievement is very high while it is found very low among others.

The difference lies in the fact that achievement motivation is believed to be learnt during socialization process and learning experiences. Gesinde (2000) further states that role models in the early life of an individual very much help a person to develop high need to achieve.

Motivation may be of two types Intrinsic and Extrinsic while intrinsic motivation is seen as an internal reward, extrinsic motivation is an incentive on reward that a person can enjoy after he or she finishes his work. Oyeok (1983) is of the opinion that motivation holds the key to the understanding of human behaviour. He says that motivation explains why an individual dodges work while the other works normally and satisfactorily enough to reach the heights. He also adds that motivation should be carefully interpreted and manipulated whether it is study or work so that our students are neither over on under motivated but appropriately motivated to achieve their best.

Harjir and Eppler (1997), Cheung (1998), Siana et al., (1998), yoloye (1976), Bridgeman (1978), Finlapson (1980), Johnson (1996), Broussard and Garrison (2004), skaalink (2004) and Sandrc (2002) have all revealed through their studies that there is a significant relationship between academic achievement and motivation.
The study conducted by Mc Celland, Airet Tella (2003) using TAT has brought to light that subjects who refer to achievement goals are often rated high in Achievement Motivation and that those who rarely or never refer to achievement goals are rated low. Besides Camera (1986) had also found that Achievement motivation is often related with actual achievement behaviour. Thus in the light of the research findings it is clear and evident that Achievement motivation is significantly associated with Academic Performance and Success of students and individuals at large.

Although several studies have been done on Academic Achievement and its correlates a few of the most important researches are highlighted here under.

Michael Benno, (1995), Harikrishnan (1992), Shah (1993), Devi and Mayuri (2003), Leeson et al., (2008), Blank (1997), Devanesan Paul (1990) Celland (1961), Rosen (1956), Striver (1958), Weiss et al., (1960), Christian (1977), Sinha (1970), Helmrich and Spence (1983) Ghuman (1977) Smith (1965) and Josh (1967).

Most of the studies highlighted above have established correlation between Achievement Motivation and Gender with that of Academic Achievement among students.

\section{Materials and Method}

\section{Objectives of the study}

1. To Study the level of Academic Achievement (AA) and Achievement Motivation (AM) of Degree students College (First year) pertaining to Arts, Science and Engineering Subjects in Puducherry.

2. To find out the relationship between Academic Achievement with that of Achievement Motivation and Gender.

Table.1

\begin{tabular}{|c|c|c|c|c|c|}
\hline Source of variation & Sum of Squares & Df & Mean Square & F & Sig. \\
\hline Between Groups & 408.634 & 2 & 204.317 & 1.444 & .238 \\
Within Groups & 43431.201 & 307 & 141.470 & & \\
Total & 43839.835 & 309 & & & \\
\hline
\end{tabular}


Table.2

\begin{tabular}{|l|c|c|c|c|c|}
\hline Source of variation & Sum of Squares & Df & Mean Square & F & Sig. \\
\hline Between Groups & 993.243 & 1 & 993.243 & 7.140 & .008 \\
Within Groups & 42846.592 & 308 & 139.112 & & \\
Total & 43839.835 & 309 & & & \\
\hline
\end{tabular}

\section{Hypothesis tested}

H.O:1 No significant relationship is identifiable between the scores of students on Academic Achievement and Achievement Motivation.

H.O:2 No significant differences are identifiable between boys and girls students with regard to their scores on Academic Achievement.

\section{Design of the study}

The present investigation was undertaken to study variables such as Achievement Motivation and Gender in relation to Academic Achievement of College students (First Year) in Puducherry.

\section{Sample}

In this study before selecting the sample, efforts were made to identify different Colleges in and around Puducherry offering Arts, Science and Engineering courses. As the variable selected are applicable for all students at College level irrespective of subjects and courses undertaken equal weightage was given to male and female students under Arts, Science and Engineering in Puducherry. The first year degree students numbering 310 in strength from various Colleges under Arts, Science and Engineering subjects constituted the Sample of the study in Puducherry.

\section{Variables}

\section{ACADEMIC ACHIEVEMENT \\ 2. ACHIEVEMENT MOTIVATION \\ 3. GENDER (SEX)}

\section{Tools used}

1. In order to assess the Academic Achievement of students the Academic Achievement Scores of First Year University Exams all coming under the jurisdiction of
Pondicherry Central University were considered to determine the level of Academic Achievement.

2. To determine the Achievement Motivation levels it was decided to use the Achievement Motivation Test prepared by Prayag Mehta.

\section{Statistical techniques}

1. Mean, Median and Standard Deviation

2. Analysis of Variance Technique (ANOVA) using SPSS

\section{Analysis and findings}

HO: 1 No significant relationship is identifiable between the scores of students on Academic achievement and Achievement Motivation.

The above hypothesis was verified using ANOVA technique. The result of the analysis it presented in Table 01 .

An examination of the above table indicates that the calculated value of ' $F$ ' is smaller than the table value of ' $F$ '. Hence the null hypothesis is accepted at 0.05 level of significance it means that achievement motivation as an independent variable does not show significant relationship with that of academic achievement of 1st year degree students in colleges in Puducherry. It may be interpreted that as far as this study is concerned no significant relationship exists between student level of Achievement motivation and that of their academic achievement scores.

HO: 2 "No significant differences are identifiable between boys and girls students with regard to their scores on academic achievement"

The above hypothesis was verified using ANOVA technique. The result of the analysis is presented in Table 02. 
The calculated value of ' $F$ ' from the above table is found to be greater than the table value. As the calculated value of ' $\mathrm{F}$ ' is greater than the table value at 0.05 level of significance the null hypothesis framed cannot be accepted. Thus it is concluded that boys and girls in their first year of college study as far as this study is concerned in Puducherry do differ much in their academic achievement. There by justifying the rejection of the null hypothesis.

It means that sex as an independent variable does show significant difference between levels of academic achievement among first year college students. It may be interpreted as far as this study is concerned that the performance of girl students is better than the performance of boys, and the level of significance achieved is 0.008 which very much highlight the significant difference between boys and girls on academic achievement scores at first year degree level, in various colleges in Puducherry.

The findings of the study have clearly established close correlation between Academic Achievement with that of Gender (Sex). As far as this study is concerned Achievement Motivation does not influence Academic Achievement of students at the First year Degree level. Thus Gender (Sex) of students is much associated and correlated with that of Academic Performance and Achievement among First year Degree students in the Union Territory of Puducherry - India.

\section{References}

Allan. 1998. Psychological factors in school achievement. Dissertation Abstracts International, Vol.58, No. 11, p.4189-A.

Ashok Kumar 2004. Current Trends in Indian Education. New Delhi: Ashish Publishing House, pp.36-38.

Chaudhury N. The Relationship between Achievement Motivation, Anxiety, Intelligence, Sex, Social Class and Vocational Aspirations Unpublished Doctoral Dissertation, Punjab University, Chandigarh,1971.

\section{How to cite this article:}

Rosalind Prabha, M. 2017. The Study of Achievement Motivation and Gender as Correlates of Academic Achievement among Degree Students in Puducherry. Int.J.Curr.Res.Aca.Rev. 5(7), 14-18.

doi: https://doi.org/10.20546/ijcrar.2017.507.003
Jagannadhan K. The Effects of Certain SocioPsychological Factors on the Academic Achievement of Children Studying in Classes V to Vii. Ph.D., Edu, SVU, 1985.

Jha V. An Investigation into Some Factors Related to Achievement in Science by Students in Secondary Schools (Doctoral Dissertation, University of Patna, 1970).

Kohli K. A Study of Interest, Achievement Motivation and Adjustment patterns of Different Socio-metric Groups of Adolescents. M.Phil. Dissertation. Pan. U., 1984.

Mansuri A.R. A Study of Achievement Motivation of Students of Stds. V, VI and VII in relation to Some Psycho-Socio Factors. Ph.D. Edu., SPU, 1986.

Munn's, L.D.F. and Peter, S.F. 2002. Introduction to Psychology. 5th Ed. New Delhi: AITBS Publishers and Distributors, pp. 329-330.

Pathak C.C. A Study of Achievement Motive, Educational Norms and School Performance of High School Pupils. Doctoral Dissertation, Sardar Patel University, 1974.

Perry, G. Stephen. 1999. The effect of psycho-social variables on the academic achievement of $8^{\prime} 1^{\prime}$ ' and 9'1' graders Dissertation Abstracts International, Vol.61, No.3, p.884-A

Promila Sharma 2005. The Aims of Education. New Delhi: APH Publishing Corporation, pp. 191-192.

Rao D.G. A Study of some Factors Related to Scholastic Achievement. Doctoral Dissertation, University of Delhi, 1965.

Seetah B.C. An Inquiry into the Psychological and Social Factors Affecting Academic Achievement. Doctoral Dissertation, Banaras Hindu University, 1975.

Suresh Batnagar and Anamika Saxeana 2006. Development of Education in India. Raj Printers, Lalbook, Meerut. pp.88-90.

Yadav, R. 2000. The vocational preferences of adolescents in relation to their intelligence and achievement. Journal of Educational Research and Extension, Vol.37, No.3, pp.36-45. 